\title{
Reproductive Performance of Wild and Hatchery-Reared Black Sea Turbot, Psetta maxima, in the Southern Black Sea Coast
}

\author{
Ilhan Aydin ${ }^{1}$, Hamza Polat ${ }^{1, *}\left(\mathbb{D}\right.$, Temel Sahin $^{2}$ \\ ${ }^{1}$ Central Fisheries Research Institute 61250 Trabzon, Turkey. \\ ${ }^{2}$ Recep Tayyip Erdoğan University, Faculty of Turgut Kıran Maritime, 53900 Rize, Turkey.
}

\section{Article History \\ Received 12June 2018 \\ Accepted 15 July 2019 \\ First Online 30 July 2019 \\ Corresponding Author \\ Tel.: +904623411053/3150 \\ E-mail: hmzplt@gmail.com}

\section{Keywords}

Black Sea turbot

Psetta maxima

Fecundity

Fertilization

Hatching rate

\begin{abstract}
In this study, spawning period, total fecundity, fertilization and hatching rates of wild and hatchery-reared turbot, Psetta maxima, were investigated. Fish were spawned over a 3-month period, from April to June. Wild broodstock consisted of sixteen females with a mean weight of $3742 \pm 1509 \mathrm{~g}$. Hatchery-reared broodstock consisted of seventeen females with a mean weight of $3604 \pm 1398 \mathrm{~g}$. Mean total fecundity was $2.4 \pm 1.71 \times 10^{6}$ and $2.3 \pm 1.75 \times 10^{6}$ eggs per female for wild and hatchery-reared broodstock, respectively. Fertilization and hatching rates were $59.2 \pm 17.07 \%$ and $67.3 \pm 30.67 \%$ for wild and $67.1 \pm 18.87 \%$ and $61.3 \pm 30.85 \%$ for hatchery-reared broodstock. The reproductive parameters of wild and hatchery reared turbot showed no significant difference, which warrants further investigation of both in provision of a sustainable fishery.
\end{abstract}

\section{Introduction}

Turbot, Psetta maxima, is one of the most valuable commercial flatfish species in Turkey. Geographic range of the turbot is wide, it occurs in European coastal waters of the Atlantic and also in the Baltic Sea, further it is even found in the Mediterranean and Black Sea (Nielsen, 1986).

In Turkey, landings of turbot decreased from 2955 $\mathrm{mt}$ in 1995 to $221 \mathrm{mt}$ in 2016. (Anonymous, 2018). The ichthyologists of the other Black Sea countries noted similar local trends (Zaitsev \& Mamaev, 1997). This decline is primarily due to overfishing, anthropogenic eutrophication and coastal destruction. Significant increases in production from wild stocks are unlikely. The increasing demand for these seafood products can only be satisfied through aquaculture and stock enhancement programs. The species has recently received interest as candidates for stock enhancement and aquaculture in Turkey. The high esteem, the demand and the high value that this species enjoy in the Turkey market led the Central Fisheries Research Institute to investigate its culture potentials, with the final objective its commercial culture on an intensive scale by the private sector, thus contributing to the aquaculture diversification in Turkey with a new and valuable fish species.

In the Black Sea, coastline of Turkey, some aspects of turbot biology are well investigated. Through studies of turbot larval rearing and growth in this region were conducted by Şahin, 2001a, 2001b; Şahin \& Üstündağ, 2003; Türker, Yiğit \& Ergün, 2005; Türker, 2006; and Aydın \& Okumuş, 2017. Broodstock management (Hara, Özongun, Güneş \& Ceylan, 2002; Başaran \& Samsun, 2004), age and growth rates (Suzuki, Kondo, Güneş, Özongun \& Ohno, 2001), development of feeding function (Kohno, Moteki, Yoseda, Sahin \& Üstündag, 2001; Moteki, Yoseda, Sahin, Ustundag \& Kohno, 2001) 
of turbot were determined. Genetic diversity and population genetics (Han, Lee, Jung, Aydin \& Lee, 2018), ecological and population parameters (Samsun, Kalaycı \& Samsun, 2007), and commercial fishing aspects (Samsun, 1995; Samsun, Kalaycı \& Samsun, 2004) of turbot were studied.

The turbot has recently been recognized as a candidate for stock enhancement and aquaculture in Turkey. Turbot is a major component of the demersal community in coastal areas of the Black Sea, however reproductive information is limited. Knowledge on fecundity and survival are important issues for planning a good production of turbot larvae and juveniles. In this study, it is aimed to elucidate the reproductive characteristics of the turbot in the South-eastern Black Sea coast, Turkey.

\section{Materials and Methods}

Data were collected from the Central Fisheries Research Institute Hatchery in Trabzon, Turkey, during the breeding season over the last 5 years. Hatcheryreared broodstock consisted of seventeen mature females (41.8-68.1 cm in total length; mean wt $3604 \pm 1398 \mathrm{~g})$. Wild broodstock consisted of sixteen females (47.4-72.3 cm in total length; mean wt $3742 \pm 1509 \mathrm{~g})$, and was collected with a trawl net by the research vessel of the Central Fisheries Research Institute (SUMAE) during a survey conducted once a week at a depth of 5-70 m off Trabzon, Turkey, during April and May. Upon arrival at the SUMAE, fish were examined and put into a quarantine tank for observation and disease treatment.

Brood fish were individually tagged and stocked at 3-4 fish per $\mathrm{m}^{2}$ in a maturation tank $(1 \times 2 \times 0.5 \mathrm{~m})$. Light intensity was kept around 100 lux using fluorescent bulbs at night and ambient conditions during daytime. The daily water exchange averaged $900 \%$ a day. Aeration was provided by two air stones with a total output of $4 \mathrm{l} / \mathrm{min}$. During spawning, the water temperature was maintained at $14.0-15.0 \circ \mathrm{C}$. The broodstock were fed whiting cut into 2-3 pieces. Feed was provided gradually until satiation.

Gonad maturation in males was examined microscopically. One drop of seawater was placed on a glass slide to which a small amount of milt was added. Sperm activity was examined under a microscope at 100 $X$ magnification. Viable sperm were characterized by whirl-like movement after seawater and milt were stirred. Gonad maturation in females was evaluated by sampling a small amount of eggs with a cannula. These were transferred to a glass slide and measured under 40 $X$ magnification. Females with at least 100 oocytes larger than $0.4 \mathrm{~mm}$ in mean diameter were considered ready to spawn (Ciftci et al., 2002).

Males with viable milt and females ready for spawning received hormonal injections. Males were injected with a mixture of human chorionic gonadotropin (HCG) and white salmon pituitary gland (WSPG; $100 \mathrm{IU} / \mathrm{kg}$ fish). Females were injected with a pelletized luteinizing hormone-releasing hormone analogue (LHRH-a; 100 g/kg fish; Berlinsky et al., 1996, Polat, Özen \&Yavuz Keskin, 2018).

Eggs were transferred into clean plastic container in and emerged in seawater. Eggs from individual fish were fertilized in seawater by gently mixing with newly stripped milt from two males. Eggs were kept about 10 minutes in the mixing container to ensure fertilization. Ten minutes after fertilization eggs were rinsed with filtered sea water. The seawater used for fertilization and rinsing the eggs was at same temperature $\left(14.3 \pm 0.13^{\circ} \mathrm{C}\right)$ as the seawater in which the broodstock were maintained. Afterward, the eggs were disinfected for 5 min in 50 ppm PVP iodine and rinsed thoroughly in filtered seawater. Unfertilized eggs did not suspend due to low salinity. Fertilization success was calculated by counting the proportion of eggs, which had started cell cleavage. The eggs obtained from each brood fish were incubated separately and as described by Sahin (2001b). The total number of eggs and fertilization rate in an incubator were estimated by the method proposed by Ciftci et al. (2002).

Data were recorded for weight and length of spawners, spawning time, total fecundity (number of eggs/female), relative fecundity (eggs/kg female), fertilization rate (at the 4-cell stage, $4 \mathrm{~h}$ after fertilization), hatching rate (ratio of hatched larvae to total number of eggs). Data were analyzed with Statistica 7.0 using variance analysis (ANOVA). The differences were tested with Tukey.

\section{Results}

Both the wild and hatchery-reared fish matured in the similar period, and spawning lasted 46 days for wild broodstock (April 8 to May 23) and 53 days for hatcheryreared broodstock (April 18 to June 9). The water temperature ranged $9-14^{\circ} \mathrm{C}$. Biometrical and reproductive parameters of broods used in this study were summarized in Table 1.

Figure 1 shows the number of eggs produced per body weight of female turbots. The egg batches stripped at $24 \mathrm{~h}$ intervals. In the wild broodstock, during 181 hand-stripping trials, a total of 39.7 million eggs from sixteen females were obtained. Female 4 was stripped eight times and produced 1.023 .660 eggs; female 9 was stripped nineteen times and produced 3.070 .080 eggs. The highest fecundity was obtained from female 10 (weight of $5841.4 \mathrm{~g}$ ) which was stripped seventeen times. In the hatchery-reared broodstock, during 156 hand-stripping trials, a total of 39.5 million eggs from seventeen females were obtained. Female 7 was stripped eight times and produced 666.450 eggs; female 1 was stripped fifteen times and produced 3.935.160 eggs. The highest fecundity was obtained from female 12 (weight of $6520 \mathrm{~g}$ ) which was stripped five times. 
Table 1. Biometrics and reproductive variables of Psetta maxima broodstock (SD: Standard deviation)

\begin{tabular}{|c|c|c|c|c|c|}
\hline \multirow[b]{3}{*}{ Variables } & \multicolumn{5}{|c|}{ Broodstock } \\
\hline & \multicolumn{2}{|c|}{ Wild $^{1}$} & \multicolumn{2}{|c|}{ Hatchery-Reared ${ }^{2}$} & \multirow[b]{2}{*}{ t-test } \\
\hline & Means $\pm S D$ & Range & Means \pm SD & Range & \\
\hline Total length $(\mathrm{cm})$ & $55.7 \pm 6.59$ & $47.4-72.3$ & $54.3 \pm 7.43$ & $41.8-68.1$ & NS \\
\hline Body weight (g) & $3742 \pm 1509$ & $2111-7788$ & $3604 \pm 1398$ & $1249-6520$ & NS \\
\hline Total fecundity $\left(10^{6}\right)$ & $2.4 \pm 1.71$ & $0.9-7.4$ & $2.3 \pm 1.75$ & $0.1-5.5$ & NS \\
\hline Relative fecundity $\left(10^{3}\right)$ & $635 \pm 254.1$ & $339-1272$ & $565 \pm 384.4$ & $69-1443$ & NS \\
\hline Fertilization rate (\%) & $59.2 \pm 17.07$ & $23.5-91.5$ & $67.1 \pm 18.87$ & $5.3-89.9$ & $*$ \\
\hline Hatching rate $(\%)$ & $67.3 \pm 30.67$ & $0.0-100$ & $61.3 \pm 30.85$ & $0.0-100$ & NS \\
\hline Spawning time & \multicolumn{2}{|c|}{08 April-23 May } & \multicolumn{2}{|c|}{18 April-09 June } & \\
\hline
\end{tabular}

*: significantly different at alevel of $\mathrm{P}<0.05, \mathrm{NS}$ : not significantly different

${ }^{1}$ Data derived from 16 fish

${ }^{2}$ Data derived from 17 fish
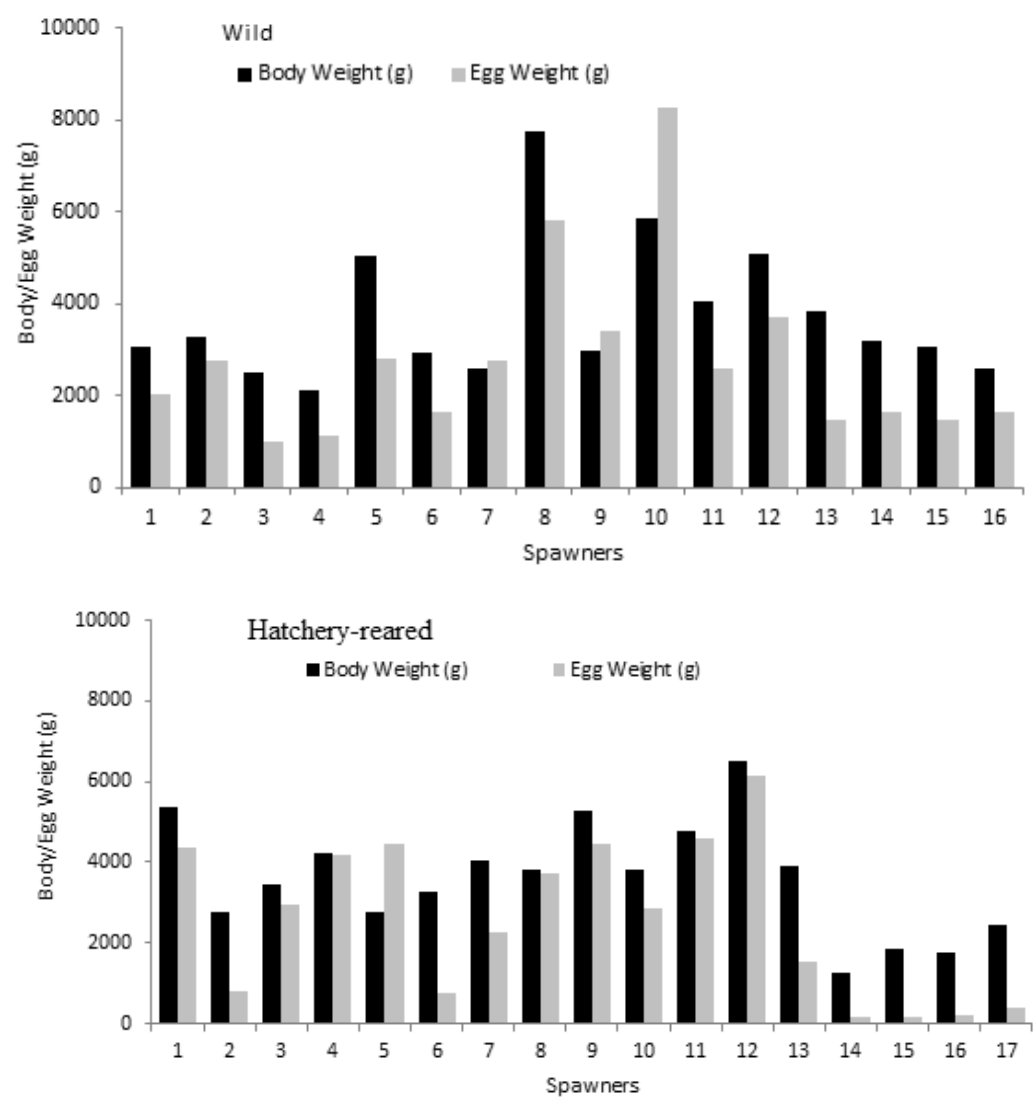

Figure 1. Egg weight and body weight of wild and hatchery-reared turbot (P. maxima).

Total fecundity exhibited a high linear relationship with body weight (Figure 2) and total length (Figure 3). Relative fecundity indicated a good positive linear correlation with body weight (Figure 4) and total length (Figure 5). Total fecundity and relative fecundity did not significantly differ between stocks (Table 1).

Fertilization rate varied between $23.5 \%$ and $91.5 \%$ (mean 59.2 $\pm 17.07 \%$ ) and between $5.3 \%$ and $89.9 \%$ (mean $67.1 \pm 18.87 \%$ ), and hatching rate ranged from $0.0 \%$ to $100.0 \%$ with a mean value of $67.3 \pm 30.67 \%$ and from $0.0 \%$ to $100.0 \%$ with a mean value of $61.3 \pm 30.85 \%$ for wild and hatchery-reared broodstocks, respectively. Although the fertilization rate significantly differed between wild and hatchery-reared broodstcoks ( $P<$ $0.05)$, differences in the hatching rates were not significant (Table 1). Positive allometries were found between fertilization and hatching rates for both broodstocks (Figure 6).

\section{Discussion}

The primary criterion of the population's reproductive capacity is the total number of eggs produced by the population during the spawning season of a given year. The mean total and relative fecundity obtained in this study were 2400000 eggs and 635000 

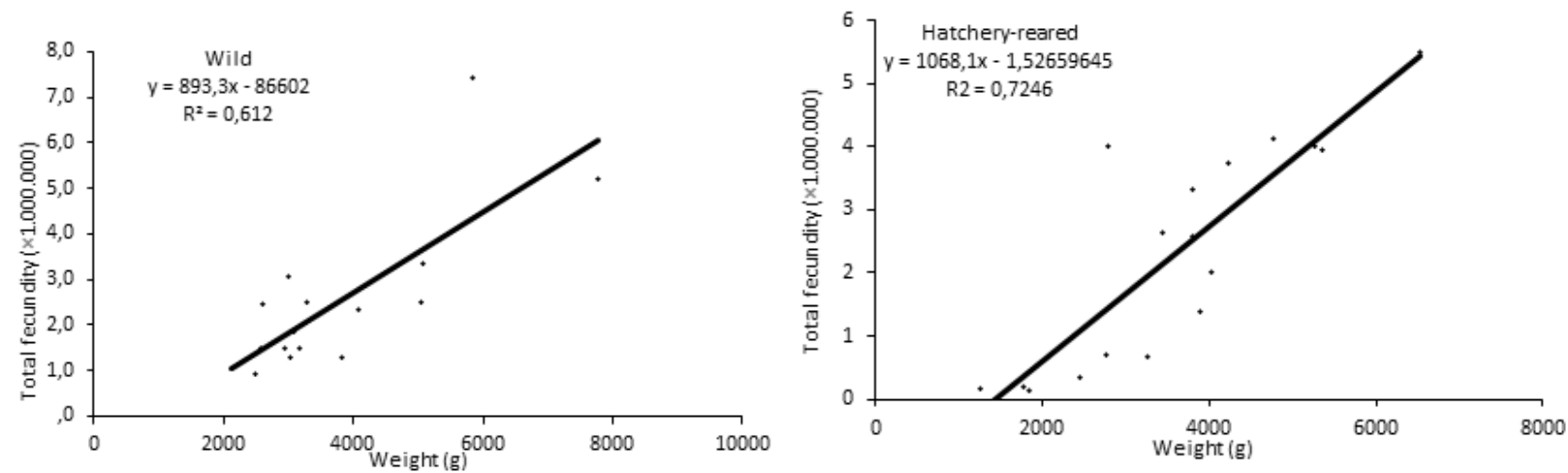

Figure 2. Relationship between total fecundity and brood weight in wild and hatchery-reared turbot (P. maxima).
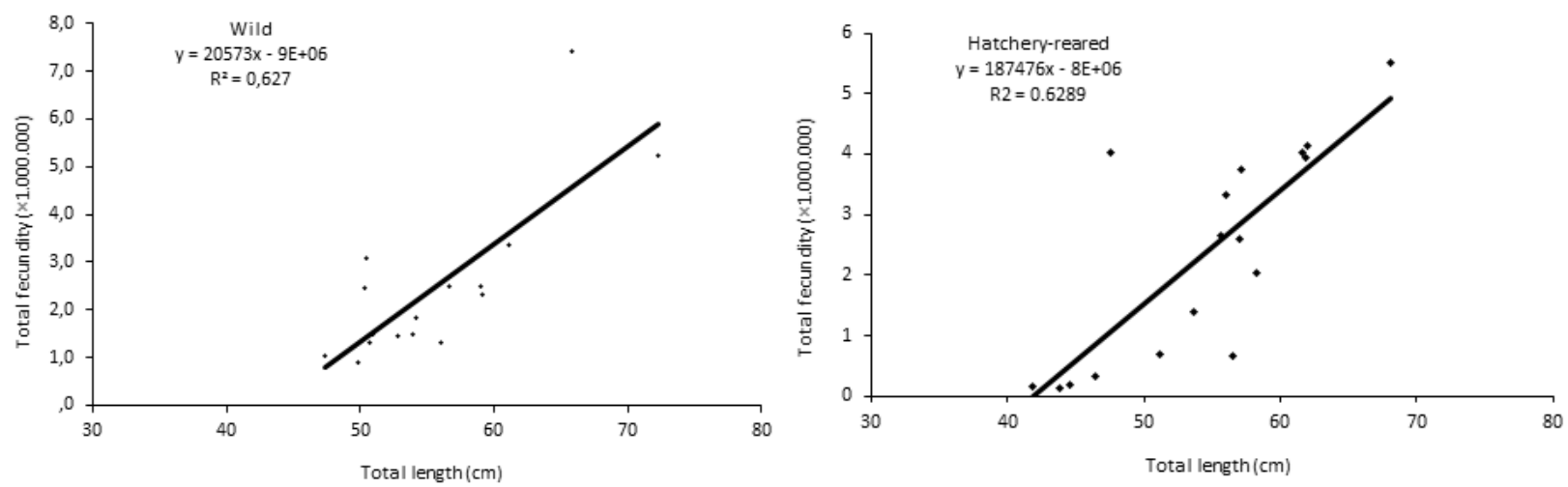

Figure 3. Relationship between total fecundity and brood total length in wild and hatchery-reared turbot (P. maxima).
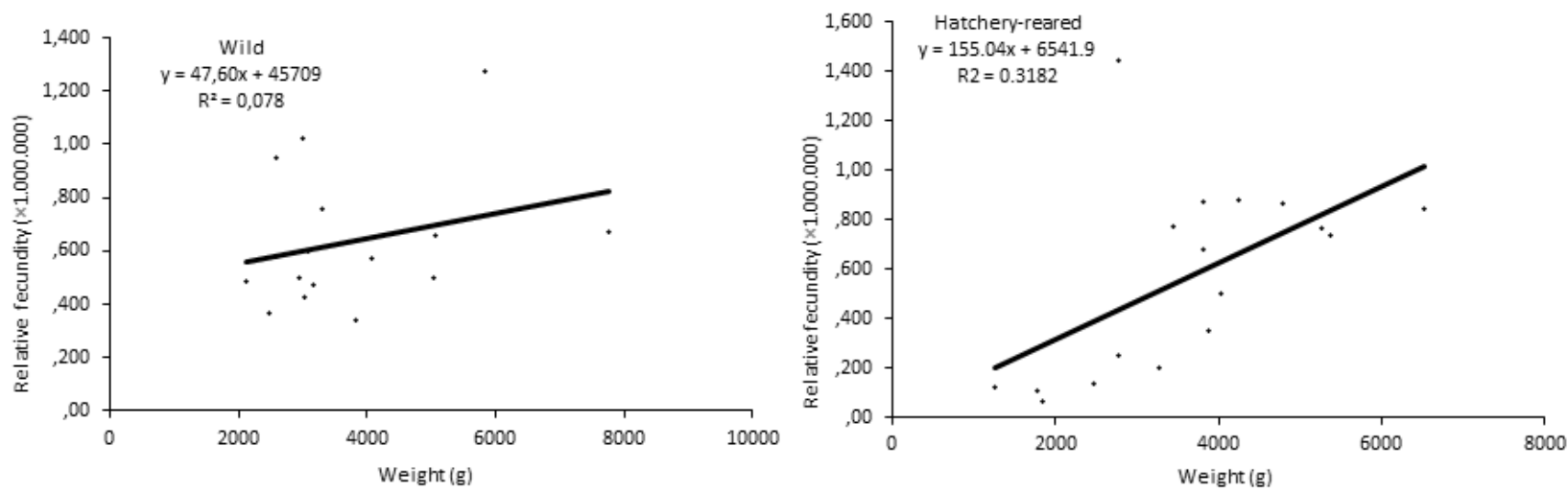

Figure 4. Relationship between relative fecundity and brood weight in wild and hatchery-reared turbot (P. maxima).

eggs $/ \mathrm{kg}$ for a fish with a mean total length of $55.7 \mathrm{~cm}$ and a mean weight of $3742 \mathrm{~g}$ in wild broods, and 2300000 eggs and 565000 eggs/kg for a fish with a mean total length of $54.3 \mathrm{~cm}$ and a mean weight of $3604 \mathrm{~g}$ in hatchery-reared broods, respectively. The study showed that the older fish was more fecund and egg production increased with increasing fish size. The fecundity in turbot is a function of size; either length or weight. The total number of eggs from a fish obtained in this study appears to be higher than those of the other flatfish species and previous studies of turbot (Table 2). This could be due to the variability of food in natural and captive conditions. The variation in fish fecundity is not only related to fish size (lenth and weight) but also to nutritional diet, running water and influence of vitamins (Marimuthu \& Haniffa, 2006). Fecundity or reproductive effort may vary in each breeding season due to differences in food supply (Treasurer, 1981), environmental conditions (Sztramko \& Teleki, 1977), and fish size (Tsai \& Gibson, 1971; Bagenal, 1978). As there is a general positive exponential relationship between fish size and number of eggs (Jenning, Kaiser, \& Reynolds, 2001), egg production in most flatfish species is positively associated with age (Bagenal, 1966). The fecundity of $P$. maxima showed large variation with size but the total and relative fecundities obtained in 

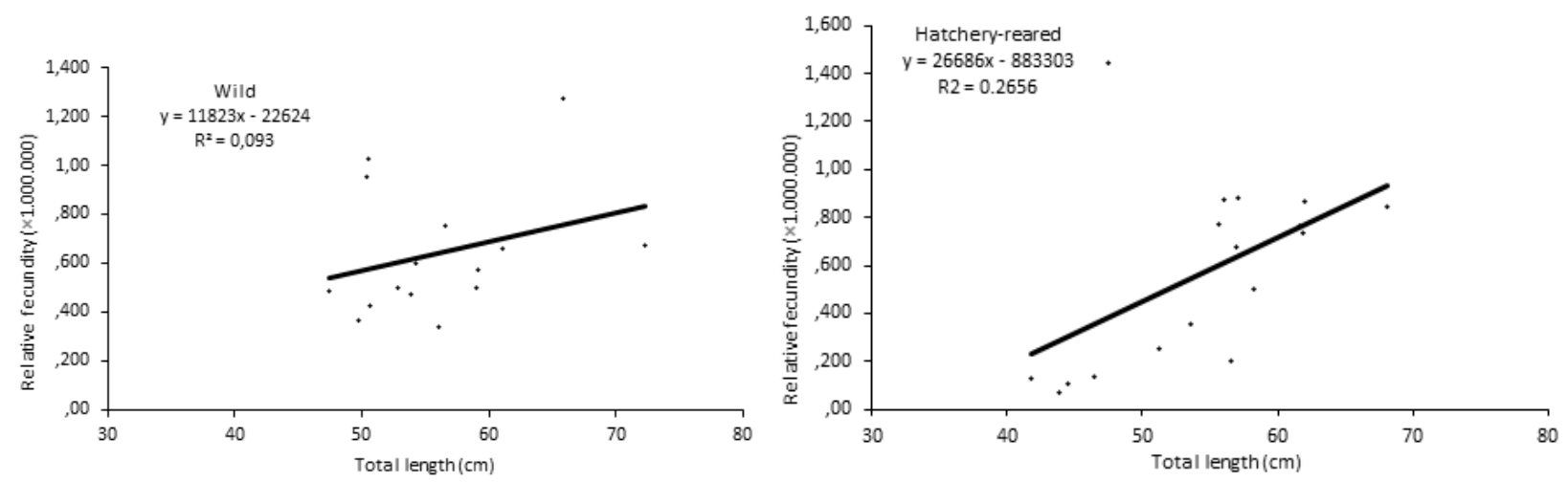

Figure 5. Relationship between relative fecundity and brood total length in wild and hatchery-reared turbot (P. maxima).
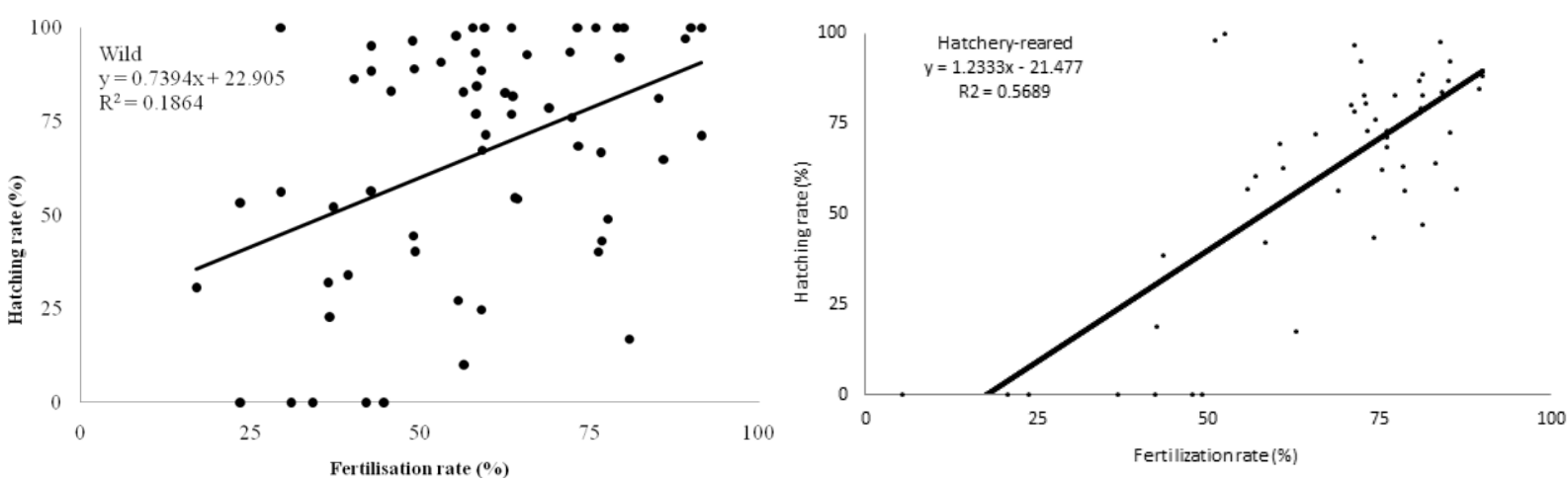

Figure 6. Relationship between fertilization rate and hatching rate of wild and hatchery-reared turbot (P. maxima).

this study had a linear relationship with body weight and total length. A similar relationship was described by Şahin, Gunes, Aydin \& Polat (2008) for flounder and by Aydın \& Şahin (2011) for the same species.

The turbot is a batch-spawning flatfish. Studies of estimates of the ovulatory periodicity of the turbot indicate that a one-day interval may characterize regular ovulation patterns (Aydın \& Şahin, 2011). Although wild females produced a mean number of 8-13 batches and batch fecundity usually remained within a range of 32580-935730 eggs, hatchery-reared females produced a mean number of 5-15 batches and batch fecundity varied between 42030-1296000 eggs during spawning season, in this study. Aydın \& Şahin (2011) reported a mean number of 7-16 batches and fecundity of 30000750000 eggs for the same species.

The correlation between fertilization rate and hatching rate in the hatchery-reared broodstock was high $\left(R^{2}=0.6128\right)$, in the wild broodstocks was low $\left(R^{2}=\right.$ $0.1864)$. Although the differences in the hatching rates between wild and hatchery-reared broodstocks were not significant, the fertilization rate significantly differed $(P<0.05)$. As observed during this strip spawning study, there was variability in fertilization success and this may be related to egg quality (Smith \& Denson, 1998). According to Bromage \& Roberts, (1996) over ripening is a significant determinant of egg quality in many fish species. The fertilization rate depends primarily on the time after ovulation (Koya, Matsubara, \& Nakagawa, 1994). Maslova (2002) found that fertilization rates of Black Sea turbot eggs decreased from $90-95 \%$ to $0 \%$ following a $24 \mathrm{~h}$ delay between the ovulation and stripping time. In this study, minimum time between the two stripped was $24 \mathrm{~h}$. Therefore, over ripening and low fertilization rates would be expected.

In conclusion, the present study demonstrated that adult Black Sea turbot, $P$. maxima, could be obtained from wild and broodstock management and artificial spawning in captivity could be achieved successfully. This study has provided some basic information on the size at sexual maturity and fecundity for turbot that will be helpful to evaluate reproductive potential of individual fish species in similar studies as well. Producing eggs at commercial scales seem to be possible, but larvae production and on-growing need long-term studies.

\section{Acknowledgements}

The authors thank to Dr. E. Küçük, M. Özongun and L. Kolotoğlu for the assistance with the field studies. Also the authors acknowledge to Dr James Furze for his great favor for languages editing manuscript based on good relationship visiting fellow ship. 
Table 2. Total and relative fecundities of different flatfish species

\begin{tabular}{llll}
\hline Species & Size & Fecundity $\left(\mathrm{x} 10^{3}\right)$ & Author/s \\
\hline P. flesus luscus & $25.2-42.0 \mathrm{~cm}$ & $79.1-318.1 \mathrm{eggs} / \mathrm{fish}$ & Şahin et al., 2008 \\
P. flesus luscus & $25.2-42.0 \mathrm{~cm}$ & $246.1-1262.7 \mathrm{eggs} / \mathrm{kg}$ & Şahin et al., 2008 \\
R. plebeia & $18-30 \mathrm{~cm}$ & $100-500 \mathrm{eggs} / \mathrm{fish}$ & Colman, 1973 \\
R. leporina & $30-45 \mathrm{~cm}$ & $250-1250 \mathrm{eggs} / \mathrm{fish}$ & Colman, 1973 \\
P. orbignyanus & $1.78-2.86 \mathrm{~kg}$ & $240-280 \mathrm{eggs} / \mathrm{kg}$ & Cerqueira et al., 1997 \\
P. orbignyanus & - & $185-399 \mathrm{eggs} / \mathrm{kg}$ & Bambill et al., 2006 \\
P. lethostigma & $1.12 \mathrm{~kg}$ & $735 \mathrm{eggs} / \mathrm{fish}$ & Watanabe et al., 2000 \\
P. lethostigma & $1.2-2.9 \mathrm{~kg}$ & $230-1000$ eggs/fish & Smith \& Denson, 2000 \\
P. maxima & $2.1-5.8 \mathrm{~kg}$ & $703-4103 \mathrm{eggs} / \mathrm{fish}$ & Aydın \& Şahin $(2011)$ \\
P. maxima & $2.1-5.8 \mathrm{~kg}$ & $184-1014$ eggs/kg & Aydın \& Şahin (2011) \\
\hline
\end{tabular}

\section{References}

Anonymous. (2018). Fisheries Statistics. State Institute of Statistics Turkish Statistical Institute, Republic of Turkey Ministry of Development

Aydin, I., \& Şahin, T. (2011). Reproductive performance of turbot (Psetta maxima) in the southeastern Black Sea. Turkish Journal of Zoology, 35(1), 109-113.

Aydın, i., Okumuş, i. (2017). Effects of Triploid Induction to the Early Cleavage Patterns of Black Sea Turbot (Psetta maxima) Embryos. Genetics of Aquatic Organisms, 1: 1520. https://doi.org/10.4194/2459-1831-v1_1_03

Bagenal, T.B. (1966). The ecological and geographical aspects of the fecundity of the plaice. J. Marine Biol. Ass. Unit. Kingdom. 46: 161186.https://doi.org/10.1017/S0025315400017628

Bagenal, T. B. (1978). Aspects of fish fecundity. Ecology of freshwater fish production, 75-101.

Bambill, G.A., Oka, M., Radonic, M., López, A.V., Müller, M.I., Bocanfuso, J.J. and Bianca, F.A. (2006). Broodstock management and induced spawning of flounder Paralichthys orbignyanus (Valenciennes, 1839) under a closed recirculated system. Revista de Biologia Marina y Oceanografia. 41(1): 45-55. https://doi.org/10.4067/S0718-19572006000100007

Basaran, F., \& Samsun, N. (2004). Survival rates of black sea turbot (Psetta maxima maeotica, L. 1758) broodstock captured by gill nets from different depths and their adaptation culture conditions. Aquaculture International, 12(3), 321-331. https://doi.org/10.1023/B:AQUI.0000036183.39217.2a

Berlinsky, D.L., King, V., Smith, T.I., Hamilton, R.D., Holloway, J., \& Sullivan, C.V. (1996). Induced ovulation of southern flounder Paralichthys lethostigma using gonadotropin releasing hormone analogue implants. Journal of the World Aquaculture Society, 27(2), 143-152. https://doi.org/10.1111/j.1749-7345.1996.tb00263.x

Bromage, N.R. 1996. Broodstock management and seed quality-General considerations. pp. 1-24. In: Bromage N.R. and R.J. Roberts (eds). Broodstock management and egg and larval quality. Blackwell Science Ltd., Oxford. 424 pp.

Cerqueira, V.R., Mioso, R., Macchiavello, J.A.G., \& Bruegger, A.M. (1997). Ensaios de indução de desova do linguado (Paralichthys orbignyanus Valenciennes, 1839). Boletim do Instituto de Pesca Sao Paulo, 24, 247-254.

Colman, J. A. (1973). Spawning and fecundity of two flounder species in the Hauraki Gulf, New Zealand. New Zealand
Journal of Marine and Freshwater Research, 7(1-2), 2143. https://doi.org/10.1080/00288330.1973.9515454

Ciftçi, Y., Üstündağ, C., Erteken, A., Özongun, M., Ceylan, B., Haşimoğlu, A., Güneş, E., Yoseda, K., Sakamoto, F., Nezaki, G. \& Hara, S. (2002). Manual for the Seed Production of Turbot, Psetta maxima in the Black Sea. Special Publication No.2, Central Fisheries Research Institute, Trabzon, $80 \mathrm{pp}$.

Han, J., Lee, W., Jung, T. S., Aydin, I., \& Lee, W. J. (2018). Evaluation of Genetic Diversity and Population Genetic Parameters of Farmed Turbot Species (Scophtalmus maximus) from France, Turkey, and Korea. Genetics of Aquatic Organisms, 2(1), 1-6. https://doi.org/10.4194/2459-1831-v2_1_01

Hara, S., Özongun, M., Güneş, E., \& Ceylan, B. (2002). Broodstock rearing and spawning of Black Sea turbot, Psetta maxima. Turkish Journal of Fisheries and Aquatic Sciences, 2: 9-12.

Jennings, S., Kaiser, M.J., \& J.D. Reynolds, (2001). Marine Fisheries Ecology. Blackwell publishing, Oxford. $432 \mathrm{pp}$.

Kohno, H., Moteki, M., Yoseda, K., Sahin, T. \& Üstündag, C. (2001). Development of swimming and feeding functions in larval turbot, Psetta maxima, reared in the laboratory. Turkish Journal of Fisheries and Aquatic Sciences. 1: 7-15.

Koya, Y., Matsubara, T., \& Nakagawa, T. (1994). Efficient artificial fertilization method based on the ovulation cycle in barfin flounder Verasper moseri. Fisheries science, 60(5): 537-540. https://doi.org/10.2331/fishsci.60.537

Marimuthu, K., \& Haniffa, M.A., (2006). Studies on fecundity of captive reared spotted snake head Channa punctatus (Channidae). Journal of Fisheries and Aquatic Science, 1(3): 291-296. https://doi.org/10.3923/jfas.2006.291.296

Maslova, O.N. (2002). Problems and achievements in seed production of the Black Sea turbot in Russia. Turkish Journal of Fisheries and Aquatic Sciences. 2: 23-27.

Moteki, M., Yoseda. K., Sahin, T., Ustundag, C. \& Kohno, H. (2001). Transition from endogenous to exogenous nutritional sources in larval Black Sea turbot Psetta maxima. Fisheries science, 67(4), 571-578. https://doi.org/10.1046/j.1444-2906.2001.00292.x

Nielsen, J.G. (1986). Scophthalmidae. In P.J.P. Whitehead, M.L. Bauchot, J.-C. Hureau, J. Nielsen, and E. Tortonese (Eds.), Fishes of the North-eastern Atlantic and Mediterranean, vol. III. Unesco, Bungay, U.K., 12871293.

Polat, H., Özen, M.R. Yavuz Keskin, S. (2018). The Embryonic Development of Black Sea Turbot (Psetta maxima 
Linnaeus, 1758) Eggs in Different Incubation Temperatures and Salinities. Turkish Journal of Fisheries and Aquatic Sciences, 18(3), 475-482. https://doi.org/10.4194/1303-2712-v18_3_13

Samsun, N., Kalaycl, F., \& Samsun, O. (2004). The determination of turbot tangle nets and trammel nets features, catch per unit effort (CPUE) and turbot fishing in Middle Black Sea (Sinop). SDÜ, Eğirdir Su Ürünleri Fakültesi Dergisi. 2: 225-234 (in Turkish).

Samsun, N., Kalaycı, F., \& Samsun, O. (2007). Seasonal variation in length, weight, and sex distribution of turbot (Scophthalmus maeoticus Pallas, 1811) in the Sinop region (Black Sea) of Turkey. Turkish Journal of Zoology, 31(4), 371-378.

Samsun, O. (1995). Research on the turbot (Scophthalmus maeoticus) of catch composition caught by the bottom trawlers in the mid Black Sea region between 1992 and 1994 fisheries season. SDÜ, Su Ürünleri Fakültesi Dergisi. 4: 225-234 (in Turkish).

Smith, T.I.J., \& Denson, M.R. (1998). Controlled spawning of southern flounder Paralichhys lethostigma: Issues and Progress. South Carolina Department of Natural Resources, UJNR Technical Report No. 28, USA.

Smith, T.I.J., \& Denson, M.R. (2000). Controlled spawning of southern flounder Paralichthys lethostigma: issues and progress. pp. 97-108. In: C. Tamaru (ed.). Spawning and Maturation of Aquaculture Species: proceedings of the twenty-eighth UJNR Aquaculture Panel 10-12 November 1999, Kihei, Hawaii. 174 pp.

Suzuki, N., Kondo, M., Güneş, E., Özongun, M. and Ohno, A. (2001). Age and growrth of turbot Psetta maxima in the Black Sea, Turkey. Tuskish Journal of Fisheries and Aquatic Sciences. 1: 43-51.

Sztramko, L., \& Teleki, G.C. (1977). Annual variations in the fecundity of yellow perch from Long Point Bay, Lake Erie. Transactions of the American Fisheries Society, 106: 578582. https://doi.org/10.1577/1548 8659(1977)106<578:AVITFO>2.0.CO;2

Şahin, T. (2001a). Effect of Water Temperature on Growth of Hatchery Reared Black Sea Turbot, Scophthalmus maximus (Linnaeus, 1758). Turkish Journal of Zoology, 25: 183-186.

Şahin, T. (2001b). Larval rearing of the Black Sea turbot, Scophthalmus maximus (Linnaeus, 1758), under laboratory conditions. Turkish Journal of Zoology, 25: 447-452.

Şahin, T., \& Üstündağ, C. (2003). Effect of Different Rearing Systems on Survival Rate of Hatchery Reared Black Sea Turbot, Scophthalmus maximus. Turkish Journal of Fisheries and Aquatic Sciences, 3: 25-27.

Şahin, T., Gunes, E., Aydin, I., \& Polat, H. (2008). Reproductive characteristics and egg development in flounder (Pleuronectes flesus luscus) in the Southern Black Sea. The Israeli Journal of Aquaculture-Bamidgeh, 60(1): 2026.

Treasurer, J.W. (1981). Some aspects of the reproductive biology of perch Perca fluviatilis L. fecundity, maturation and spawning behavior. Journal of Fish Biology, 18(6), 729-740. https://doi.org/10.1111/j.10958649.1981.tb03814.x

Tsai, C., \& Gibson, G.R. (1971). Fecundity of the yellow perch, Perca flavescens Mitchill, in the Patuxent River, Maryland. Chesapeake Science, 12:270-284. https://doi.org/10.2307/1350914

Türker, A. (2006). Effect of feeding frequency on growth, feed consumption, and body composition in juvenile turbot (Psetta maxima Linaeus, 1758) at low temperature. Turkish Journal of Veterinary and Animal Sciences, 30(2), 251-256.

Türker, A., Yiğit, M., \& Ergün, S. (2005). Growth and feed utilization in juvenile Black Sea turbot (Psetta maeotica) under different photoperiod regimes. Turkish Journal of Veterinary and Animal Sciences, 29(5), 1203-1208.

Watanabe, W.O., Carroll, P.M., \& Daniels, H.V. (2000). Recent progress in controlled reproduction of southern flounder Paralichthys lethostigma. pp. 141-148. In: C. Tamaru (ed.). Spawning and Maturation of Aquaculture Species: proceedings of the twenty-eighth UJNR Aquaculture Panel 10-12 November 1999, Kihei, Hawaii. 174 pp.

Zaitsev, Y., \& Mamaev, V. (1997). Marine biological diversity in the Black Sea. A study of change and decline. GEF Black Sea Environmental Series, 3, 208. 